\title{
REFERENCIAÇÃO E MARCAS DE CONHECIMENTO PARTILHADO
}

\author{
Mônica Magalhães Cavalcante* \\ Leonor Werneck dos Santos ${ }^{* *}$
}

Resumo: Pretendemos, com este ensaio, demonstrar, em gêneros de três domínios discursivos distintos, como os interlocutores recorrem mais, ou menos, a conbecimentos prévios, ainda que apenas supostamente compartilhados, para reelaborar os referentes e os sentidos do texto. Nossa análise incidirá sobre as diversas recategorizações de objetos de discurso, por parte do leitor, em dêiticos, introduções referenciais e anáforas, diretas e indiretas. Assumimos o pressuposto de Apothéloz e Pekarek-Dobler (2003), já reconbecido em trabalhos anteriores (CAVALCANTE, 2011), de que o referente não se introduz $e$ nem sempre se mantém no texto somente pela explicitação de expressões referenciais. Com isso, refletiremos sobre como a reconstrução desses referentes não bomologados na superfície do texto se confirma pela recorrência a mecanismos inferenciais mais complexos e sempre se orienta por trilhas estruturais (LIMA, 2003, LEITE, 2007).

Palavras-chave: Leitura. Conhecimento partilhado. Referenciação.

\section{INTRODUÇÃO}

Quando falamos de leitura e compreensão de textos, é comum lembrarmo-nos de tarefas escolares como "Quem fez o quê, quando e onde?”. Algumas dessas atividades vão além do que está óbvio no texto e buscam inferências, mas não com muita frequência encontramos análises relacionando as estratégias de referenciação presentes nos textos a conhecimentos que, dentro de gêneros pertencentes a certos domínios discursivos, são exigidos do coenunciador, em maior ou menor grau, para a elaboração de um percurso argumentativo.

A leitura depende, dentre outros fatores, de uma representação de intencionalidades e de percepções, e a identificação de estratégias de referenciação colabora para traçar o percurso dos sentidos do texto. Por isso, a argumentação depende direta, embora não exclusivamente, de

\footnotetext{
* Professora Associada da Universidade Federal do Ceará - UFC. Doutora em Linguística pela Universidade Federal de Pernambuco - UFPE. Email: monicamc02@gmail.com.

** Professora Associada da Universidade Federal do Rio de Janeiro - UFRJ. Doutora em Letras Vernáculas pela Universidade Federal do Rio de Janeiro - UFRJ. Email: leonorwerneck@gmail.com.
} 
estratégias de referenciação. Pretendemos, com este ensaio, demonstrar como os interlocutores sempre recorrem a conhecimentos prévios, ainda que apenas supostamente compartilhados, para reelaborar os sentidos do texto a partir dos fenômenos de referenciação. A partir daí, podemos estabelecer reflexões interessantes sobre outros fenômenos da linguagem.

Nossa análise incidirá sobre a identificação de objetos de discurso, por parte do leitor, em introduções referenciais e anáforas, diretas e indiretas. Assumimos o pressuposto de Apothéloz e Pekarek-Dohler (2003), já reconhecido em trabalhos anteriores (cf. CAVALCANTE, 2011), de que o referente não se introduz e nem sempre se mantém no texto somente pela explicitação de expressões referenciais. Como bem afirma Lima (2003), a reconstrução desses referentes não homologados na superfície do texto se confirma pela recorrência a mecanismos inferenciais mais complexos, mas sempre se orientam por trilhas estruturais (cf., principalmente, LEITE, 2007).

\section{LEITURA, REFERENCIAÇÃO E CONHECIMENTO PARTILHADO}

Segundo Koch e Elias (2006, p. 13, grifos das autoras), "Nossa atividade de leitores ativos em interação com o autor e o texto começa com antecipações e hipóteses", sendo a leitura, portanto, uma atividade estratégica de levantamento de hipóteses, conforme objetivos específicos, associando o conhecimento do código linguístico a outros conhecimentos prévios. Para Marcuschi (2008), só faz sentido falar de leitura quando consideramos o conceito de compreensão, e não "copiação" de informações soltas no texto - como o autor classifica as atividades propostas nas escolas. Assim, é necessário que o leitor associe informações, levante hipóteses, faça inferências.

Por isso, para Koch e Elias (2006, p. 21), “a leitura e a produção de sentidos são atividades orientadas por nossa bagagem sociocognitiva: conhecimentos da língua e das coisas do mundo". Segundo Kleiman (1992), ao ler, acionamos conhecimentos prévios - linguísticos, textuais, enciclopédicos, intertextuais, contextuais, dentre outros -, conforme a situação interacional, que colaboram para a construção de sentidos do texto, como podemos observar no Quadro 1, a seguir. 


\section{Quadro 1: Conhecimentos prévios}

- conhecimento textual - refere-se à nossa percepção de como se organizam os textos. Assim, por exemplo, constatamos que estamos lendo uma receita quando identificamos a organização típica de lista de ingredientes e modo de fazer, quando percebemos o objetivo desse gênero textual (ensinar a fazer uma torta, por exemplo).

- conhecimento linguístico - refere-se à experiência linguísticodiscursiva, como noções de construção de frases, valores semânticos, uso de afixos. Retomando o exemplo da receita, quando identificamos sua estrutura injuntiva típica, percebemos, principalmente, verbos com valor imperativo.

- conhecimento enciclopédico (também chamado conhecimento de mundo) - refere-se a tudo o que assimilamos no decorrer da nossa vida, desde noções de quantidade a conceitos como doce/amargo, passando por informações históricas, sociais, culturais etc. Portanto, ao ler um texto, sempre retomamos, de certa forma, na nossa memória, o que já lemos e conhecemos, para fazer inferências e compreender o texto que está na nossa frente.

- conhecimento intertextual - colabora para identificarmos as referências, explícitas ou implícitas, a outros textos. Assim, diante de um livro intitulado $A$ verdadeira história dos três porquinhos, ${ }^{1}$ se conhecemos a versão tradicional desse conto de fadas, logo imaginamos que estamos diante de uma história que a retoma, apresentando algum fato novo, como um final diferente, por exemplo. Nesse caso, o título começa com "a verdadeira história", o que remete para a desconfiança de que a outra versão seria falsa (percebemos isso pelo nosso conhecimento linguístico, semântico, da palavra "verdadeira"): e o livro, de fato, pretende apresentar uma nova versão, a do Lobo Mau, que se considera injustiçado, pois não teve culpa de derrubar as casas dos porquinhos. É necessário ressaltar, porém, que a não identificação do texto-fonte da intertextualidade não impede a compreensão, apenas dificulta a percepção de algum aspecto peculiar do texto que retoma outro.

- o conhecimento contextual - refere-se à associação do texto a ser lido com o contexto de leitura e de produção. Isso equivale a dizer, em linhas gerais, que contextualizar significa também perceber intencionalidades interacionais. Por exemplo, ao ouvirmos uma frase como "Depois eu falo com você lá fora", vinda, amistosamente, de um amigo que está ocupado, ou de um professor, em tom pouco amistoso, percebemos pela situação interacional se devemos ficar felizes ou preocupados com o aviso de que a conversa continuará "lá fora".

Fonte: Adaptação de Santos, Cuba Riche e Teixeira (2012, p. 42-43)

\footnotetext{
${ }^{1}$ SCIESZKA, Jon. A verdadeira história dos Três Porquinhos. 2. ed. São Paulo: Cia. das Letrinhas, 2005. 
O acionamento desses conhecimentos prévios, que são separados apenas por questões didáticas, é essencial para a construção dos sentidos, que incluem a reelaboração de referentes. Assim, a compreensão de uma intencionalidade sarcástica numa frase como "Antônia é papa-hóstia" depende da identificação do significado da expressão papa-hóstia, da percepção do valor negativo dessa expressão (em alguns contextos) e da associação feita entre esse valor negativo e determinado comportamento religioso - além do conhecimento de quem é Antônia. Construir a coerência desse enunciado, portanto, depende sempre de os interlocutores partilharem conhecimentos. Por isso, Koch e Elias (2006, p. 184, grifos das autoras) afirmam que

A coerência não está no texto, não nos é possível apontá-la, destacá-la, sublinhá-la ou coisa que o valha, mas somos nós, leitores, em um efetivo processo de interação com o autor e o texto, baseados nas pistas que nos são dadas e nos conhecimentos que possuímos, que construímos a coerência.

Penetrar o sentido de um texto implica, necessariamente, engendrar diversos processos referenciais. A construção da referência é um processo dinâmico; dependendo das relações intertextuais e interdiscursivas, por vezes, ela se move sobre ambiguidades contextuais, exacerbando ainda mais esse dinamismo, que exige do leitor maior elasticidade nas expectativas que cria.

Em todo texto/discurso, o enunciador constrói a referência com base numa interpretação do mundo real, recategorizando a informação precedente ao acrescentar novas predicações, disponíveis, em diferentes medidas, no conhecimento das pessoas, à medida que transcorre a interação. Por esse aporte de informação nova, o enunciador conduz o destinatário (que coparticipa dessa construção, sendo, por isso, um coenunciador) a uma reinterpretação ou refocalização do elemento referido. Pelas estratégias de recategorização, a imagem do referente que o coenunciador constrói em sua memória vai evoluindo à medida que se desenvolve o discurso. 
Discutiremos, a seguir, a relação profícua entre processos referenciais, conhecimentos compartilhados e gêneros de diferentes domínios discursivos: jornalístico (relatos de jogos de futebol), literário (contos) e humorístico (gêneros diversos). Nossa intenção é demonstrar como os processos referenciais constroem trilhas de sentido ao sinalizarem para a busca de diferentes informações na memória discursiva dos participantes da enunciação. Veremos como o desconhecimento de dados específicos pode comprometer a reelaboração dos objetos de discurso, como nos relatos esportivos, e como, por outro lado, o conhecimento partilhado é recategorizado dentro do discurso literário de modo a construir um cenário particular, um mundo próprio, que repercute nas marcas anafóricas. Também mostraremos como a recategorização de referentes promove a queda de expectativas e colabora fundamentalmente para a criação do cômico em gêneros humorísticos.

\section{MARCAS DE CONHECIMENTO PARTILHADO NA REFERENCIAÇÃO EM RELATOS DE JOGO}

Conforme já afirmamos, ao ler um texto, percebemos a relação entre seus elementos, mas, além disso, é necessário associá-los ao projeto de dizer do texto. Quando estamos diante de elementos de retomada/antecipação de objetos de discurso, observamos de que maneira ocorrem as estratégias de referenciação: atividade discursiva de construção de sentidos.

Para exemplificar, analisaremos dois relatos esportivos de um dos jogos da Copa do Mundo de 2010: o texto 1, retirado do Jornal Lance!, especialmente voltado para esportes (cf. MORAIS, 2012); o texto 2, retirado do site do Jornal Diário Popular (Pelotas/RS).

\section{Texto 1: Passaram os dois}

Chile perde para a Espanba, termina em segundo e será o rival do Brasil. Time de Bielsa foi ousado, mas apresenton erros fatais.

O Chile foi derrotado por 2 a 1 pela Espanha. Perdeu a liderança do Grupo H para o rival, mas foi beneficiado pelo empate da Suíça em 
Honduras. Avançou em segundo lugar e será o rival da Seleção Brasileira nas oitavas de final da Copa do Mundo.

Resta saber qual a estratégia que os Locos de Bielsa terão contra os brasileiros. Afinal, eles são capazes de tudo. Nas duas primeiras rodadas se lançaram ao ataque e venceram sem discussão Honduras e Suíça. Ontem, encarando uma Espanha, que pela primeira vez teve seus quatro ases desde o início (Xavi, Iniesta, Villa e Torres), trataram de sufocar $\underline{\text { }}$ rival, mesmo só precisando do empate para avançar sem tomar conhecimento do jogo suíço.

Mas, apesar de toda a sua estratégia ousada - desta vez cinco jogadores focados no ataque -, o Chile mostrou deficiências que foram fatais e que devem ser bem observadas por Dunga e pela comissão da Seleção.

Uma delas: a marcação é muito viril e isso ocasiona um caminhão de cartões. Tanto que o time tinha oito pendurados ontem. E antes dos vinte minutos, Medel, Ponce e Estrada estavam amarelados. Aliás, o Chile foi a única seleção que fez 20 ou mais faltas em todos os seus jogos.

Mais: o frenético toque de bola gera erros de passes que geram contraataques. Foi assim aos 24. Valdívia errou, a Fúria ligou o contra-ataque para Fernando Torres pela esquerda, com apenas um na marcação. Isso fez o goleiro Bravo sair atabalhoadamente para a dividida que sobrou para Villa chutar da intermediária, de primeira, num lance de beleza e precisão.

Atrás pela primeira vez nesta Copa, o Chile se desnorteou. E os erros de passe aumentaram. Num deles, Iniesta recuperou a bola e depois concluiu para o gol. 2 a 0.

A partir daí, a Espanha administrou. Até porque o Chile teve um expulso (Estrada) no lance do gol e precisou se resguardar lá atrás.

$\mathrm{Na}$ etapa final, o time de Bielsa voltou mais cauteloso. Chegou a diminuir com Millar. Mas quem sempre esteve perto de fazer gols foi a Espanha, quase sempre após erros de passe do Chile. Nos quinze minutos finais não teve jogo. O Chile ficou bem fechadinho (estaria se preparando para jogar assim contra o Brasil?) e a Espanha foi tocando bola.

Agora, a Fúria pega Portugal. Jogão! O Chile encara o Brasil sem dois de seus zagueiros titulares Medel e Ponce. E aí, Bielsa, vai se lançar ao ataque contra a Seleção? Olha bem o que a Espanha fez.

Fonte: VIEIRA, Carlos Alberto. Passaram os dois. Jornal Lance!, Rio de Janeiro, 26 jun. 2010, p. 20. (grifos nossos). 


\section{Texto 2: Chile e Espanha avançam e enfrentam Brasil e Portugal}

JOHANNESBURGO, África do Sul (AFP) - A Espanha derrotou o Chile por 2 a 1 e avançou como primeiro do Grupo $\mathrm{H}$ às oitavas de final da Copa do Mundo, onde enfrentará Portugal, enquanto os chilenos sobreviveram graças ao empate por 0 a 0 entre Honduras e Suíça, e na próxima fase pegam o Brasil.

Em Pretória, a equipe de Vicente del Bosque venceu a de Marcelo Bielsa com gols de David Villa (24) e Andrés Iniesta (37), enquanto Rodrigo Millar (47) descontou para o time sul-americano, que jogou com dez após a expulsão de Marco Estrada na jogada do segundo gol espanhol.

Fonte: Diário Popular (2012, grifos nossos). ${ }^{2}$

Além disso, no texto 1, as expressões "Time de Bielsa" e "Locos de Bielsa" - presentes logo no início do relato - e o pronome "eles" parecem ter mais de um possível referente textual, mas se referem aos chilenos - o que pode ser percebido, com algum esforço, pela percepção da manutenção do tópico central (cf. JUBRAN, 2006). Podemos dizer, portanto, que são os indícios cotextuais, neste caso, que ajudam a homologar as relações anafóricas, de tal modo que, mesmo quem desconhece por inteiro o assunto, é capaz de, com sua competência textual, relacionar "Time de Bielsa", "Locos de Bielsa" e "eles" ao time do Chile. É curioso como, nesta situação de desconhecimento do assunto, o coenunciador é levado a se inteirar dos epítetos do mundo do futebol e de inúmeras outras expressões, quer referenciais, quer não, peculiares a esse discurso. Mas se deve reconhecer que não somente o conhecimento textual das amarrações anafóricas atua nesse processo, pois, não fossem as informações mínimas dos coenunciadores sobre o que é futebol, o que é um campeonato e como ele funciona, as dificuldades de compreensão seriam muito maiores. Esta é a razão pela qual o leitor menos proficiente nem sempre consegue reconstruir a contento a coerência dos textos a que tem acesso na escola e na vida cotidiana.

Uma dificuldade de outra ordem se percebe no uso da expressão anafórica correferencial "a Fúria”, que também se reporta à seleção

\footnotetext{
${ }^{2}$ Disponível em: < http://www.diariopopular.com.br/site/content/ noticias/detalhe.php?id=4\& noticia $=21787>$. Acesso em: 13 fev. 2012

CAVALCANTE; SANTOS - Referenciação e marcas...
} 
espanhola, mas quem não acompanha futebol pode não conseguir recuperar esse objeto de discurso no relato esportivo em análise. Observamos que o apelo ao conhecimento específico do tema é bem maior neste caso, de maneira que, se o leitor não tiver desenvolvido bem a habilidade de restabelecer as ligações coesivas e as relações entre segmentos tópicos no cotexto, essa coerência local não será alcançada. Por outro lado, se o leitor estiver a par do que se passa no domínio discursivo do futebol, o esforço para recuperar as relações anafóricas será bem menor.

Importa ainda atentar para o fato de o jornalista ter selecionado a expressão anafórica "a Fúria”: isso implica uma escolha e a definição de uma dada condução argumentativa, via expressão referencial. Ao optar por usar "a Fúria”, em vez de "seleção espanhola”, "os espanhóis” ou qualquer outra expressão referencial, o enunciador reitera uma das características da seleção espanhola, na época da Copa de 2010: o engajamento e o ímpeto dos jogadores de uma equipe considerada uma das melhores do mundo - fato que se confirmou com sua vitória inédita ao final desta Copa.

Também precisamos fazer inferências ao lermos dois outros elementos do primeiro relato: "rival", que aparece no texto quatro vezes, refere-se ora aos espanhóis, ora aos chilenos. Nesta situação específica, em que as expressões anafóricas correferenciais são idênticas, mas os referentes são distintos, o que mais se exige do coenunciador é a sua competência para realizar os encadeamentos tópicos e, pelo contexto, entender quem é adversário de quem, a cada enunciado que emprega a expressão "o rival". Além disso, o uso de "rival" reforça a metáfora da guerra, muito comum em textos sobre esporte (cf. TEIXEIRA, 2004), e destaca o caráter de disputa típico de jogos de Copa do Mundo.

Já "estratégia ousada" encapsula toda a informação anteriormente citada no cotexto e retomada adiante, referente à jogada dos chilenos para vencer os espanhóis, o que requer do leitor a habilidade de, com base em seus conhecimentos de mundo sobre futebol, encontrar no cotexto as informações resumidas pela anáfora encapsuladora "estratégia ousada": a tática dos chilenos de "se lançar ao ataque', com "marcação muito viril" e "frenético toque de bola" - o que, segundo o texto, gera "um caminhão de cartões" e "erros de passe". 
Não podemos deixar de destacar, porém, a diferença entre ambos os textos: o primeiro necessita de mais inferências; o segundo parece mais destinado a um leitor não necessariamente inteirado do assunto, porque se vale menos de recursos lexicais do discurso futebolístico e se alinha mais ao discurso jornalístico de um modo geral, o que explica a seleção de expressões anafóricas mais informativas, como "a equipe de Vicente del Bosque venceu a de Marcelo Bielsa", recuperáveis no cotexto devido à manutenção tópica. Ainda assim, o leitor que não compartilhar dos dados sobre os técnicos dos times da Espanha e do Chile pode não estabelecer uma ligação precisa aos antecedentes, ou âncoras, desses anafóricos. Um raciocínio equivalente vale para o emprego da expressão "o time sul-americano", no texto 2 , que requer um conhecimento geográfico geral sobre o continente em que se encontra o país de origem de cada time.

Outra hipótese para esse descompasso entre textos que pertencem ao mesmo gênero é a peculiaridade do suporte em que aparecem (cf. MORAIS, 2012). O texto 1 foi publicado num jornal especialmente voltado para esportes, cujos leitores geralmente são aficionados por futebol, já assistiram ao jogo ou sabem do resultado, mas querem mais detalhes da partida, anseiam por comentários, críticas e curiosidades; portanto, partilham de informações que auxiliam na recuperação dos objetos de discurso. Já o texto 2 foi publicado num jornal generalista, na seção de esportes, o que pressupõe leitores não necessariamente conhecedores de futebol. Essa diferença pode explicar por que, no texto 1, há tantas informações que necessitam de mais inferências para serem interpretadas. Assim, o que, para quem não entende de futebol, pode representar um enigma (qual é o "Time de Bielsa": Chile ou Espanha?), para o público do Jornal Lance!, é mais facilmente compreendido.

Além disso, é importante perceber como as escolhas referenciais colaboram no projeto de dizer, marcando uma orientação argumentativa. Vejamos, mais detalhadamente, os casos de "Locos de Bielsa" e "estratégia ousada", no texto 1.

A opção por nomear a seleção chilena como "os Locos de Bielsa" denota muito mais que simplesmente uma retomada: exige um conhecimento prévio do leitor sobre quem é o técnico do time chileno (Bielsa), sobre o seu apelido desde os tempos em que jogava na Argentina ("El Loco"), sobre o idioma falado pelo técnico (espanhol) e 
sobre a associação feita por alguns comentaristas de futebol quando chamam de loucos, por extensão, os jogadores das equipes comandadas pelo técnico argentino Marcelo Bielsa; além disso, implica uma percepção da polissemia da palavra 'loucos', associada, nesse caso, à ousadia, à irreverência e à coragem do time e do técnico. Uma curiosidade é que, no texto 1, "Locos de Bielsa" se refere à seleção chilena da Copa de 2012, mas, a partir de 2011, a mesma expressão aparece em referência ao novo time treinado por Bielsa, o Athetic de Bilbao, na Espanha, como observamos em textos jornalísticos publicados no Brasil e no exterior ${ }^{3}$ :

Algunos, los llaman rojiblancos; otros, los guerreros de Bilbao; unos más, los locos de Bielsa; y la mayoría los idolatra al nombrarlos los leones de San Mamés. ${ }^{4}$

No texto 1, a fama de louco do técnico e dos seus jogadores uma vez que a predicação termina se estendendo também aos jogadores ao longo do texto - é reforçada pela expressão "estratégia ousada, criando uma metáfora entre jogo e guerra (intensificada pelas expressões referenciais "o rival", "deficiências que foram fatais", "o ataque") e que encapsula o estilo de jogo dos chilenos: ênfase no ataque, sem preocupação com a defesa, causando a derrota contra a Espanha, o que colocou em risco a chance de ir para a etapa seguinte da Copa do Mundo. A expressão "estratégia ousada" também colabora para a construção da imagem da equipe chilena, apresentada reiteradamente como uma seleção que se arrisca e que pode não conseguir a vitória desejada na Copa, uma loucura, enfim. Esse ponto de vista é reforçado na provocação feita pelo jornalista no último parágrafo: "E aí, Bielsa, vai se lançar ao ataque contra a Seleção?”

Percebemos, portanto, com esses dois textos, como as estratégias de referenciação colaboram para a construção de sentidos do texto e dependem do acionamento de conhecimentos prévios linguísticos,

\footnotetext{
3 Cf. também <http://www.diaadia.com.ar/deportes/con-dos-higuain-goleo-real-madrid>, <http://www.sharkfoot.fr/2012/03/schalke04-athletic-club-bilbao-notes/>

4 Disponível em: http://navegandoporelatlantico.blogspot.com.br/2012/03/san-mames-del-mitola-realidad.html. Acesso em 9 out. 2012.
} 
enciclopédicos e contextuais, além da percepção da estrutura textual dos relatos, do suporte em que se encontram e da orientação argumentativa.

Veremos, em seguida, como os referentes se constroem dentro de outro domínio discursivo, o literário, e como as especificidades do universo discursivo criado por cada texto literário enreda o leitor no mundo próprio da ficção.

\section{O APELO A CONHECIMENTOS PARTILHADOS NO DISCURSO LITERÁRIO}

Sabemos que a construção da referência é uma só para todo tipo de discurso e que, no discurso literário, o que muda é o modo de referir do escritor e o modo de interpretar do leitor. Nas palavras de Whiteside (1987, p. 197):

deve existir um pacto não escrito entre escritor e leitor de que o escritor está referindo, não no mundo real, mas em sua própria interpretação do mundo real, ou em seu próprio mundo criado, ou em ambos. [...] esta "ilusão referencial" é uma das fontes de prazer do leitor.

A interação entre os contextos é de fundamental importância para a referência, a qual, constituindo um ato de fala, faz parte do ambiente cultural e ideológico de escritores e leitores. Mas o referente literário não é interpretado somente a partir dos valores sociais. A obra literária não nasce da sociedade apenas, mas dos conflitos existentes no campo literário.

O escritor não enuncia sua obra num contexto neutro e estável, pois pertence, ao mesmo tempo, ao campo literário e à sociedade e não se fixa exclusivamente em nenhum deles. A enunciação literária desestabiliza qualquer noção de lugar; é como se o escritor, movendo-se entre o lugar e o não lugar, pairasse numa localização parasitária, a que Maingueneau (1995, p. 28) chamou de "paratopia": durante a produção do discurso literário, vários domínios se intercondicionam: o tipo de elaboração determina o tipo de pré-difusão ou de publicação (as reações do primeiro círculo que lê a obra); por sua vez, o tipo de publicação visada orienta a forma e o conteúdo do texto. 
Com apoio nesta visão, analisemos a construção da referência no conto literário "Dizem que os cães veem coisas", de José Maria Moreira Campos. Atentemos para a forma como certas personagens são referidas ao longo dos discursos e para o modo como o leitor pode recriar o significado dos textos a partir do contexto literário em interpretação.

Dentro da realidade ficcional, o plano narrativo objetivo corresponderia ao mundo do "fazer crer", enquanto o plano subjetivo corresponderia ao "real". O relacionamento entre "real" e "fazer crer" assinala Whiteside (1987, p. 198) - "é simbiótico, cada um emprestando significado e potencial referencial ao outro".

A interpretação do referente literário é determinada, ainda, pela reação do leitor ao identificar o gênero a que pertence o discurso, o que pode restringir seu conjunto de expectativas. Este reconhecimento inclui não somente variedades discursivas, como também escolas ou movimentos literários a que se filia o escritor.

Em "Dizem que os cães veem coisas", é justamente a multiplicidade de contextos condicionadores que induz o leitor a identificar o referente do pronome "ela", que abre inesperadamente o conto, sem remeter a absolutamente nenhuma entidade expressa no texto. "Ela" é a morte: seus traços o sugerem; a reação das pessoas o confirma:

\section{Texto 3 - Início}

Ela chegou diáfana, transparente, no vestido branco que lhe descia até os pés calçados pelas ricas sandálias de pluma. Ninguém lhe ouviu os passos. Sentou-se à beira da grande piscina, cruzando as pernas longas. Chegou antiquíssima, atual e eterna, com a sua cara de máscara. Moldada em gesso? Apenas uma presença, porque pousou como uma sombra. Mas por um fragmento de tempo, um quase nada, reinou entre todos um silêncio largo, que se estendeu pelo vasto terreno murado da mansão ensombrada pelas árvores, dominou a enorme piscina e emudeceu as próprias crianças pajeadas pelas babás de aventais bordados, e vejam que as crianças são indóceis.

Um presságio.

Fonte: CAMPOS, Moreira. Dižem que os cães veem coisas. 2. ed. São Paulo: Maltese, 1993. p. 151. 
Também a vida do escritor influencia sobremaneira sua produção, mas nela não se reflete como uma imagem especular. Suas experiências de vida, de algum modo, sempre presentes no discurso literário, passaram antes pelo prisma da criação. Reciprocamente, a obra participa da vida do escritor, pois ele só existe em função do que produz: "O que se deve levar em consideração não é a obra fora da vida, nem a vida fora da obra, mas sua difícil união" (cf. MAINGUENEAU, 1995, p. 46), sua "bio/grafia", uma expressão criada por Maingueneau para, a um só tempo, unir e separar os dois termos, focalizando esta relação de permanente instabilidade.

A expectativa do leitor é que o "ela", como todo anafórico, retome um elemento presente no cotexto (não importa se antes, ou depois). Mas, no texto, o pronome inicial termina por não se ligar a expressão referencial nenhuma no cotexto, embora o referente seja construído por numerosas pistas deixadas no cotexto e que são fundamentais para a correferencialidade. Sobra, para o leitor, o encargo de construir uma referência que o cotexto lhe forneceu não de forma evidente, mas velada. Entretanto, essa aparente "insuficiência" de dados tem um significado especial que só o conjunto dos contextos do discurso literário pode revelar. A enunciação literária rompe, desse modo, com os padrões do discurso ordinário para obter novas relações de sentido.

Assim, "ela", neste caso, não retoma do cotexto o SN autônomo a morte. Este é apenas indiciado. Sem dúvida, para identificar o referente de "ela", sem confundi-lo com o referente de outras ocorrências do mesmo pronome, é preciso que o leitor reconstrua muitos aspectos da cena enunciativa que se passa dentro da narração e que se valha do conhecimento enciclopédico para assentar os mosaicos que caracterizam a morte. Deve atentar, por exemplo, para uma adjetivação que não se aplica a entidades humanas, como "diáfana, transparente, trespassável, antiquíssima, atual e eterna", além da descrição culturalmente aceita da morte com "cara de máscara", como que "moldada em gesso", que "parecia consultar no pulso um relógio invisível, para marcar o tempo". Deve notar também que o referente descrito tem caráter imperceptível, captável apenas pelo narrador onisciente: "ninguém lhe ouviu os passos", "apenas uma presença, porque pousou como uma sombra". E deve, principalmente, observar a carga semântica da expressão "um 
presságio", que, conotando tragicidade, constitui, sozinha, uma frase nominal curta, ou, mais do que isso, um parágrafo, além de tudo, isolado por um espaço tipográfico.

A morte como pressentimento se revela na própria frase que intitula o conto e que aparece no texto mais duas vezes. Na primeira ocorrência, surge num parágrafo que interrompe o cenário festivo e é introduzido como um parentético:

\section{Texto 3: Meio}

Os cães de raça latiam e uivavam desesperadamente nos canis (e dizem que os cães veem coisas). Foi preciso que o tratador viesse acalmá-los, embora eles rodassem sobre si mesmos e rosnassem. A distância, a piscina quase olímpica, agora deserta, toalhas esquecidas, o vidro do bronzeador, o cinzeiro sobre a mesinha cheio de pontas de cigarro marcadas de batom.

Fonte: CAMPOS, Moreira. Dižem que os cães veem coisas. 2. ed. São Paulo: Maltese, 1993. p. 153.

Os parênteses acentuam a ideia de presságio, ao mesmo tempo em que o sujeito indeterminado, em "dizem", sugere uma afirmação supersticiosa. Como um recurso de modalização do discurso (MOURA NEVES, 1996), o indeterminante representa uma marca de impessoalização, que evidencia a tentativa de não assumir o dito

A história transcorre numa festa que comemora o aniversário da dona da mansão. Em meio à fartura, aos goles de uísque e a futilidades, eis que o filho da aniversariante escapa aos olhos distraídos da babá. Queda um pressentimento. Ninguém dá conta do menino. Quando a mãe se sobressalta com a ausência, já é tarde: o garoto é encontrado morto na piscina.

Atestada a morte, o narrador torna a referir-se aos cães: "Os cães de raça voltavam a latir desesperadamente, e dizem que os cães veem coisas". Por último, o texto se encerra com a repetição parcial do primeiro parágrafo, como para confirmar o presságio: 


\section{Texto 3: final}

O médico novo, de calção, tentou a respiração artificial, o boca-a-boca (os lábios de Netinho estavam arroxeados) e levantou-se sem palavras e sem olhar para ninguém. Lenita soltou-se e agarrou-se ao filho:

- Acorde, acorde! Pelo amor de Deus, acorde!

Conseguiram afastá-la mais uma vez, quase desmaiou. A amiga limpavalhe com os dedos a sobra de farofa que se grudara ao seu rosto. Os cães de raça voltavam a latir desesperadamente, e dizem que os cães veem coisas.

Lenita ficou para sempre com a sensação do corpo inerte e mole entre os braços. Uma marca, presença, que procurava desfazer com as mãos. Cabelos louros e gotejantes. Às vezes, ela despertava na noite:

- Acorde! Acorde!

A presença também daquele instante de silêncio que pesara sobre a piscina. Um pressentimento apenas? Precisamente o momento em que Ela chegara, transparente e invisível, e se sentara à beira da piscina, cruzando as pernas longas, antiquíssima, atual e eterna.

Fonte: CAMPOS, Moreira. Dižem que os cães veem coisas. 2. ed. São Paulo: Maltese, 1993. p. 154.

Observe-se, finalmente, a personificação da morte pela maiúscula: "Ela". A inominável, pois a simples enunciação de seu nome já mete arrepios...

Este conto evidencia o quanto o contexto de vida do escritor, do autor como figura humana, real, se perpetua, em muitos aspectos, nos fatos que narra, embora não se esteja falando de um locutor empírico, mas de uma representação dele. Moreira Campos perdeu tragicamente um neto, morto por afogamento. Por este e por outros motivos, talvez, a morte é temática constante em sua obra. Seu modo de encará-la é sempre eivado de respeito. Diante do inexplicável, demonstra uma atitude mística de quem se rende ao sobrenatural. É a vida se inscrevendo na obra, e a obra reescrevendo, em parte, a vida.

Desse modo, a interpretação do referente literário depende de todos os contextos interseccionados. Além do contexto do escritor, do leitor, do conhecimento intratextual, intertextual e extratextual, uma narrativa literária opera dinamicamente com um duplo cenário 
enunciativo: o da história contada e o da narração dessa história. $\mathrm{O}$ primeiro se refere ao ambiente da própria ficção; o segundo, à enunciação do narrador dirigida a um leitor.

No conto de Moreira Campos, os dois contextos enunciativos deixam traços linguísticos explícitos, o que nem sempre ocorre em narrativas ficcionais. Nem sempre a voz do enunciador - que, necessariamente, existe, porque todo texto deve ser atribuído a alguém se faz ouvir no discurso narrado; em geral, ela apenas subjaz ao enunciado. É essa VOz que expressa a interioridade do sujeito da enunciação na tentativa de envolver o coenunciador. É ela que determina os diversos tons que deve assumir o enunciado através do narrador.

O final do parágrafo que abre o texto, por exemplo, revela uma das marcas da voz de um enunciador que crê no sobrenatural. É quando o narrador, impondo o tom meio místico que percorrerá todo o conto, dirige-se ao leitor: "e emudeceu as próprias crianças pajeadas pelas babás de aventais bordados, e vejam que as crianças são indóceis".

O sujeito gramatical de "vejam", "vocês", remete diretamente ao referente do possível destinatário da enunciação, a uma representação do leitor. Constitui, pois, um elemento dêitico de pessoa.

Num mesmo enunciado, convivem, assim, os dois mundos, as duas localizações: a da narração, que é situacional, e a do fato narrado, que é textual. Mais dois momentos do discurso acomodam harmonicamente esta cenografia dupla: precisamente, nas duas ocorrências que retomam o título "e dizem que os cães veem coisas", em que o narrador implicitamente dialoga com o leitor. Notemos que, em ambos os casos, o leitor percebe a separação entre os espaços, o campo dêitico e o campo não dêtico, reconstruindo sem conflitos os dois contextos.

Escolher um personagem secundário como narrador tem consequências importantes na caracterização da referência e, consequentemente, na manipulação dos sentidos. É como optar por um narrador participante da história, mas cujo ponto de vista se restringe ao de um narrador não onisciente.

Além de todos os níveis contextuais inter-relacionados, na reconstrução dos referentes, o leitor do texto literário deve, pois, considerar a interveniência do foco narrativo no modo de referir. 
Conforme dissemos, para referir, não é preciso sempre designar; às vezes, apenas sugerimos ou apontamos algo criando uma situação discursiva referencial.

A elaboração do quadro de referentes dentro do domínio discursivo literário é, portanto, singular: difere bastante, por exemplo, da referenciação construída no domínio discursivo jornalístico e mais ainda nos relatos de futebol discutidos acima. Além de conhecimentos de mundo e de informações específicas sobre os temas abordados, exigidos nos relatos esportivos, os objetos de discurso dos contos literários requerem do leitor uma imersão no entorno ficcional e um engajar-se nele. Os conhecimentos compartilhados solicitados podem ser de toda ordem - históricos, filosóficos, literários -, mas todos conduzem o coenunciador a firmar um pacto com o narrador, de modo a se assumir dentro da cenografia criada.

\section{A CONSTRUÇÃO DA REFERÊNCIA EM TEXTOS DE HUMOR}

No discurso humorístico, os processos de recategorização dos referentes se dão, em um grande número de ocorrências, a partir de alusões interdiscursivas, em que os objetos de discurso são recriados com base em valores e crenças presentes na cultura em que se disseminam as piadas. Vejamos um exemplo:

Texto 4: $\mathrm{O}$ que escrever em seu túmulo, se você é....

ESPÍRITA

Volto já.

INTERNAUTA

www.aquijaz.com.br

ALCOÓLATRA

Enfim, sóbrio.

HISTORIADOR

Enfim, fóssil. 


\section{BROTHER}

Fui.

\section{DELEGADO}

Tá olhando o quê? Circulando, circulando...

\section{ECOLOGISTA}

Entrei em extinção.

FUNCIONÁRIO PÚBLICO

É no túmulo ao lado.

\section{VICIADO}

Enfim, pó!

Fonte: Disponível em: <http://www.bandeiradois.xpg.com.br/o-queescrever-em-seu-tumulo-se-voce-e/>. Acesso em 15 abr. 2012.

No texto 4, cada expressão referencial em caixa alta tem uma representação discursiva em nosso meio social: cada uma revestida de estereótipos nos quais se incluem formas recorrentes no discurso de cada uma dessas identidades, como no caso do delegado, representando o discurso policial "Circulando, circulando"; ou do ecologista, tratando de animais em extinção; ou do viciado em cocaína, que só pensa no pó da droga - "Enfim, pó". O humor só surte efeito se o leitor tiver armazenados esses conhecimentos em sua memória discursiva, de modo a compreender que as frases ligadas a cada expressão anafórica indireta aludem comportamentos atribuídos à imagem do funcionário público, por exemplo, a quem a sociedade imputa atitudes de preguiça e de má vontade. Para entender por que a frase "Volto já" está associada ao espírita, é preciso saber, para alcançar a comicidade, que a doutrina espírita crê na vida após a morte e na reencarnação.

Muitos dos textos humorísticos parecem ser alimentados por imagens preconceituosas, como no exemplo a seguir:

\section{Texto 5: A BALANÇA}

A loira entra na farmácia segurando um bebê e pergunta ao balconista se pode usar a balança de bebê. 
- Lamento, minha senhora, nossa balança que pesa bebês está no conserto. Mas, podemos calcular o peso do bebê, se pesarmos a mãe e o bebê juntos, na balança de adulto. Em seguida, pesamos a mãe sozinha e subtraímos o segundo valor do primeiro!

- Ah! Isso não vai dar certo - diz a loura.

- Por que não?

- Porque eu não sou a mãe, sou a tia!!!!

Fonte: Disponível em:

<http://br.answers.yahoo.com/question/index?qid=20101221165848A Alj0Vh>. Acesso em 15 abr. 2012.

É curioso notar que, em piadas desta natureza, o coenunciador já espera que o teor do texto verse sobre parvoíces e imbecilidades, uma vez que se convencionou atrelar as mulheres louras a reações parvas e tolas. Assim sendo, quando a loira, suposta mãe, é recategorizada como tia, apenas se homologa a expectativa do leitor de que a narrativa discorresse sobre alguma atitude típica de uma "loira burra" - e este é o conhecimento cultural mais solicitado no contexto, embora nenhuma expressão referencial explicite esse preconceito.

Como afirma Lima (2003, p. 115-116):

Dentre as ocorrências analisadas, podemos observar que a maioria parece ser motivada por estruturas já estabilizadas no nosso sistema conceitual. Supomos que a universalidade do acesso ao gênero piada, que independe de classe social ou de nível de escolarização, a constante exposição a textos anedóticos e as suas consequentes repetições facilitam a estabilização dos frames criados com o propósito humorístico, os quais, não podemos esquecer, estão intimamente relacionados às crenças e aos valores culturais. (...) Entretanto, há uma outra parte de ocorrências que parece ser motivada por estruturas conceituais novas, ainda não estabilizadas, que emergem no momento da enunciação, com a construção do significado dessas ocorrências só sendo possível em razão do contexto em que se inserem. 
Outra imagem muito estigmatizada em textos humorísticos é a da mulher, que, em geral, vem depreciada no atravessamento de um discurso machista. Essa cultura machista aparece em diferentes graus e, ainda que disfarçada ou apenas insinuada, está geralmente presente, como no texto 6:

\section{Texto 6}

Um dia minha mãe saiu e deixou meu pai tomando conta de mim.

Eu tinha uns dois anos e meio. Alguém tinha me dado um "jogo de chá" de presente, e era um dos meus brinquedos favoritos.

Papai estava na sala vendo o Jornal Nacional, quando eu trouxe para ele uma "xícara de chá", que na realidade era apenas água. Após várias xícaras de chá, em que recebia elogios entusiasmados do papai a cada xícara servida, minha mãe chegou.

Meu pai a fez se sentar na sala, para me ver trazendo a ele uma xícara de chá, porque era "a coisa mais fofa do mundo!". Minha mãe esperou, e então, vinha eu pelo corredor com uma xícara de chá para o papai, e ela o viu beber todo o chá.

Então ela disse (apenas uma mãe saberia):

- Passou pela sua mente que o único lugar que ela alcança água é na privada????

\section{Os pais não pensam igual às mães...}

Fonte: Disponível em: http://forum.jogos.uol.com.br/Um-dia-minhamae-saiu-e-deixou-meu-pai-tomando-conta-de-mim_t_982776. Acesso em 15 abr. 2012.

Nessa piada, o narrador se assimila ao ponto de vista das mulheres-mães, o que se denuncia pela frase parentética: "apenas uma mãe saberia". Cria-se no universo discursivo do texto um discurso antimachista, sustentado pela imagem da mulher que tem ciência de tudo o que se passa dentro de casa, que cuida mais dos filhos que o pai e que, por isso mesmo, é a única a perceber que o marido bebera água da privada, dada pela filha em xícaras de chá de brinquedo. A figura do pai é meio ridicularizada, sobretudo com o uso da expressão recategorizadora, em tom irônico, "a coisa mais fofa do mundo", indiretamente enunciada por ele. 
Em contextos assim, não é a explicitação de expressões referenciais que desencadeia o humor, mas os processos referenciais que se elaboram implicitamente. Os indícios do cotexto convocam os conhecimentos partilhados na cenografia em que o pai se desmancha de mimos ante os pequenos gestos da filha. Tais indícios se manifestam não apenas por expressões referenciais aparentemente não cômicas, mas também por predicados inteiros, como no trecho: "em que recebia elogios entusiasmados do papai a cada xícara servida"; em atenuadores, como "era apenas água"; em expressões atitudinais, como "um dos meus brinquedos favoritos" ou "elogios entusiasmados".

Por vezes, o texto humorístico requer do coenunciador um conhecimento cultural mais amplo. Quando isso acontece, é possível que não se compreenda por inteiro que referentes são recategorizados de modo a, nessa transformação, produzirem um efeito cômico. É o que podemos observar no texto 7 , em que as categorias são recriadas para aquela instância enunciativa, atendendo ao propósito comunicativo de criar uma situação cômica:

\section{Texto 7: Efeitos colaterais da crise grega}

\section{ÚLTIMAS NOTÍCIAS:}

1. Hércules acaba de ser demitido dos seus 12 trabalhos e procura bico como segurança na casa de tolerância de Vênus.

2. Afrodite foi rodar bolsinha na esquina.

3. Hades começou a vender suco de soja.

4. Atenas entrou em liquidação e mudou seu nome para "Apenas". [...]

6. Sem dinheiro para pagar uma diarista, Zeus muda o nome de seu lar de "Olimpo" para "Ossujo".

7. Multidão na Acrópole protesta para que Aquiles trate seu calcanhar no SUS.

8. Medusa de dia faz bico na ala das cobras em zoológico e à noite transforma pessoas em pedras e vai vender na "Cracolândia".

9. A Acrópole acaba de ser vendida e em seu lugar será inaugurada uma Igreja Universal do "Reino de Zeus."

10. Asclépio (deus da medicina) decidiu suspender o atendimento aos planos de saúde. 
11. A deusa Atena acaba de ser vista trabalhando como garçonete em lanchonete da rede Mcdonald, nos USA.

12. Narciso vendeu seus espelhos para pagar dívida do cheque especial. 13. Pandora montou uma pequena empresa para produção de caixas de embalagem. [...]

Disponível em: http://br.groups.yahoo.com/group/Mad_Page_Cool_ Mails/message/386. Acesso em 16 fev. 2012.

O leitor precisaria ter conhecimento, em primeiro lugar, que, em 2012, a Grécia vem enfrentando medidas de contenção de despesas e aumentos de impostos, na tentativa de escapar a uma grave crise econômica que se abateu sobre a Europa. Precisaria entender que o mundo anda meio cético quanto à habilidade da Grécia em implementar cortes de gastos orçamentários e que, por esta razão, o país tem sido motivo de troça. Para além disso, o leitor precisaria ter conhecimentos mínimos sobre mitos e lendas da Grécia antiga, para compreender as predicações relativas a cada referente mencionado no texto. Deveria saber, por exemplo, quais são os deuses citados e o que caracteriza cada um deles: saber que Zeus é o deus de todos os deuses e senhor do Céu; Afrodite é a deusa do amor, sexo e beleza; Hades é o deus das almas dos mortos, dos cemitérios e do subterrâneo; Atena é a deusa da sabedoria e da serenidade, protetora da cidade de Atenas, dentre outros conhecimentos solicitados ao leitor.

É importante atentar para o fato de que, nesta ocorrência, os conhecimentos são solicitados via processos intertextuais de referência e de alusão. Segundo Piègay-Gros (1996), a referência é um dos tipos de intertextualidade por copresença (cf. GENETTE, 1982). Ocorre quando um texto remete a outro sem necessariamente haver citação de um trecho dele. A remissão pode realizar-se, por exemplo, por meio da nomeação do autor do intertexto, do título da obra e/ou de personagens de obras literárias. No exemplo em apreço, há, logo de início, a uma referência ao maior herói da mitologia grega: Hércules. Filho de Zeus com Hera, quando ainda um menino, Hércules conseguiu matar um leão selvagem e, na vida adulta, foi responsável, conforme reza o mito, pelas maiores e mais espetaculares aventuras atribuídas aos heróis gregos, razão por que foi cantado nas artes em geral. 
Tal fenômeno intertextual, ao referir-se a Hércules, alude, ao mesmo tempo, às histórias contadas sobre ele, culturalmente repetidas. A alusão é uma espécie de referência "implícita", pois não apresenta marcas tipográficas que costumam assinalar a citação (embora saibamos que nem toda citação é introduzida por sinais de pontuação). Por isso, seu reconhecimento demanda maior capacidade de inferência por parte do enunciador. No texto 7 , por exemplo, os sentidos não seriam alcançados se o leitor não tivesse o conhecimento básico de que a Hércules se atribui a realização dos famosos doze trabalhos - pedidos quase impossíveis feitos por Euristeu, Rei de Argos de Micenas, ou que tenha pelos menos conhecimento da expressão "os doze trabalhos de Hércules".

Assim, cada uma das referências intertextuais, no texto 7 , alude às histórias narradas em torno dos deuses e dos heróis mencionados pela mitologia grega. Por razões de espaço, não aprofundaremos os comentários sobre este exemplo. Ademais, o essencial é ter em mente que o tipo de inferência aqui exigido se faz por meio de processos intertextuais.

\section{CONSIDERAÇÕES FINAIS}

Com base nas análises que efetuamos neste ensaio, é possível perceber como os processos referenciais são essenciais para a construção de sentido do texto, colaborando para a perspectiva argumentativa, para a manutenção tópica, para a construção e recategorização dos objetos de discurso.

Assim, quando pensamos em relacionar a referenciação ao ensino, é crucial destacarmos a importância desse processo na leitura e na produção de textos. Trabalhar a referenciação em sala de aula implica articular leitura, análise linguística e produção textual, uma vez que "Para compreender um texto, é necessário relacionar os elementos de retomada à construção de seu sentido" (SANTOS; CUBA RICHE; TEIXEIRA, 2012, p. 20). Além disso, implica também relacionar esse processo aos gêneros textuais, pois faz parte da constituição dos gêneros o uso de marcas linguísticas específicas. Trabalhar com referenciação em sala de aula, portanto, significa formar leitores e produtores críticos e envolvidos com a importância sociocognitiva e histórica das estratégias textual-discursivas. 


\section{REFERÊNCIAS}

APOTHÉLOZ, D.; PEKAREK-DOHLER, S. Nouvelles perspectives sur la référence: des approches informationnelles aux approches interactionnelles. Verbum, Presses Universitaires de Nancy, Tome XXV, n. 2, 2003. p. 109-136.

CAVALCANTE, M. M. Referenciação: sobre coisas ditas e não ditas. Fortaleza: UFC, 2011.

CIULLA E SILVA, A. Os processos de referência e suas funcões discursivas - o universo literário dos contos. 2008. 212f. Tese (Doutorado em Linguística)-Centro de Humanidades, Universidade Federal do Ceará, Fortaleza, 2008.

GENETTE, G. Palimpsestes: La littérature au second degré. Paris: Seuil, 1982.

JUBRAN, C. C. A. S. Tópico discursivo. In: ; KOCH, I. (Orgs.).

Gramática do português culto falado no Brasil - construção do texto falado. Campinas: EdUnicamp, 2006. p. 89-132.

KLEIMAN, A. B. Texto e leitor aspectos cognitivos da leitura. 2. ed. Campinas: Pontes, 1992.

KOCH, I. V.; ELIAS, V. M. Ler e compreender: os sentidos do texto. São Paulo: Contexto, 2006.

LEITE, R. L. Metaforização textual: a construção discursiva do sentido metafórico no texto. 2007. 212f. Tese (Doutorado em Linguística) - Centro de Humanidades, Universidade Federal do Ceará, Fortaleza, 2007.

LIMA. S. M. C. de. (Re)categoriz̧ação metafórica e humor: trabalhando a construção dos sentidos. 2003. 150f. Dissertação (Mestrado em Linguística)-Universidade Federal do Ceará, Fortaleza, 2003.

MAINGUENEAU, D. O contexto da obra literária. Trad. de Marina Appenzeller. São Paulo: Martins Fontes, 1995.

MARCUSCHI, L. A. Produção textual, análise de gêneros e compreensão. São Paulo: Parábola, 2008.

MORAIS, M. Processos de referenciação nos relatos esportivos. 2012. 112f. Dissertação (Mestrado em Língua Portuguesa)-Faculdade de Letras, UFRJ, Rio de Janeiro, 2012.

MOURA NEVES, M. H. A modalidade. In: KOCH, I. G. V. (Org.). Gramática do português falado. Campinas, SP: Editora da UNICAMP/ FAPESP, 1996. v 6., p. 163-169. 
SANTOS, L. W.; CUBA RICHE, R.; TEIXEIRA, C. de S. Análise e producão de textos. São Paulo: Contexto, 2012.

TEIXEIRA, C. de S. A metáfora na argumentaşão. 2004. 200f. Tese (Doutorado em Língua Portuguesa) - Faculdade de Letras, UFRJ, Rio de Janeiro, 2004.

WHITESIDE, A. On referring in literature. Bloomington and Indianapolis: Indiana University Press, 1987.

Recebido em: 30/07/2012. Aprovado em: 25/10/2012.

Title: Referenciation and markers of shared knowledge

Authors: Mônica Magalhães Cavalcante; Leonor Werneck dos Santos

Abstract: The goal of this essay is to demonstrate, in three genres of three different discourse domains, how speakers resort in a higher or lower degree to previous knowledge, even if they are only supposedly shared, to reconstruct referents and meanings of the text. The analysis will cover the various recategorizations of objects of discourse made by the reader in deictics, referential introductions and in direct and indirect anaphors. It is assumed as in Apothéloz and Pekarek-Dobler (2003), and already recognized in former works (cf. CAVALCANTE, 2011) that the referent is not introduced and is not always kept in the text only by explicit referential expressions. Hence it will be discussed how the reconstruction of those referents not explicitly given on the text surface is confirmed by resorting to more complex inferential mechanisms, and how it is always guided by structural tracks.

Keywords: Lecture. Shared knowledge. Referenciation.

Titulo: Referenciaciación y marcas de conocimiento compartido

Autores: Mônica Magalhães Cavalcante; Leonor Werneck dos Santos

Resumen: Pretendemos, con este ensayo, demostrar, en géneros de tres dominios discursivos distintos, como los interlocutores recurren más, o menos, a conocimientos previos, aunque apenas supuestamente compartidos, para reelaborar los referentes y los sentidos del texto. Nuestro análisis incidirá sobre las diversas recategorizaciones de objetos de discurso, por parte del lector, en déicticos, introducciones referenciales y anáforas, directas e indirectas. Asumimos el supuesto de Apotbéloz y Pekarek-Dobler (2003), ya reconocido en trabajos anteriores (CAVALCANTE, 2011), de que el referente no se introduce y ni siempre se mantiene en el texto solamente por la explicitación de expresiones referenciales. Con esto, reflexionaremos sobre como la reconstrucción de esos referentes no homologados en la superficie del texto se confirma por la recurrencia a mecanismos inferenciales más complejos y siempre se orienta por caminos estruturales (LIMA, 2003, LEITE, 2007).

Palabras-clave: Lectura. Conocimiento compartido. Referenciación. 